\title{
Sequence Stratigraphy and Depositional Environment of the Zubair Formation in Rumaila Oilfields, Southern Iraq: Microfacies and Geochemistry
}

\author{
Hamid A. A. Alsultan', Salih M. Awadh ${ }^{2}$, Mohanad R. A. Al-Owaidi ${ }^{1, *}$, and Amer J. Al-Khafaji ${ }^{1}$ \\ ${ }^{1}$ Department of Applied Geology, College of Science, University of Babylon, Babylon, Iraq \\ ${ }^{2}$ Department of Geology, College of Science. University of Baghdad, Baghdad, Iraq \\ *Correspondence: sci.mohanad.rasim@uobabylon.edu.iq
}

Received: 6 June 2021; Accepted: 7 July 2021; Published: 31 August 2021

\begin{abstract}
In the Rumaila oilfields in southern Iraq, the Zubair Formation was deposited in a shallow environment as three main facies, delta plain, backshore, and delta front depositional conditions indicating a transition from delta front and delta plain to a highstand level due to the finning upward mode. The facies of the Zubair clasts show well-sorted quartz arenite sandstone, poorly sorted quartz arenite sandstone, clayey sandstone that has not been properly sorted, sandy shale, and shale lithofacies. The minor lithofacies were identified using well-logging methods (gamma ray, spontaneous potential and sonic logs) and petrography. The Zubair clasts are of transition environment that appears to be transported from freshwater and deposited in a marine environment forming many fourth-order cycles reflect sea level rise fluctuations and still-stand under tectonics developed the sequence stratigraphy. A misalignment between relative sea-level and sediment supply caused asymmetry sedimentary cycles. A shallower environment of shale-dominated rocks rich in organic matter and pyrite were exposed. The basinal shale of Ratawi at the Zubair bottom and the shallow carbonate of Shuaiba emplace on the Zubair represent the beginning of the delta build up (delta front and delta plain) to a highstand stage.
\end{abstract}

Keywords: Zubair Formation; Rumaila; Quartz; Stratigraphy; Petrography; Geochemistry

\section{Introduction}

The Zubair Formation is the most important reservoir and source rock of oil in the early Cretaceous period. In Iraq and neighboring countries to the northeast of the Arabian Plate, the Zubair Formation is of widespread extension (Buday, 1980). The Zubair Formation became very important and considered the most promising oil-bearing rock unit since 1948 when the international oil company (IOC) had drilled the first oil well in southern Iraq. The Zubair, Ratawi and Shuaiba Formations are part of the Thamama Group and belongs to the Late Barremian-Aptian sedimentary cycles in which, the Zubair units have heterogeneity of organic matter content that eventually affect permeability (Awadh, 2018; Awadh et al., 2019). The studied region is located in the Mesopotamian zone's southernmost unit within the Zubair subzone (Fig. 1). This area was uplifted during the Hercynian movement and then subsided after the Late Permian (Jassim and Guff, 2006). 


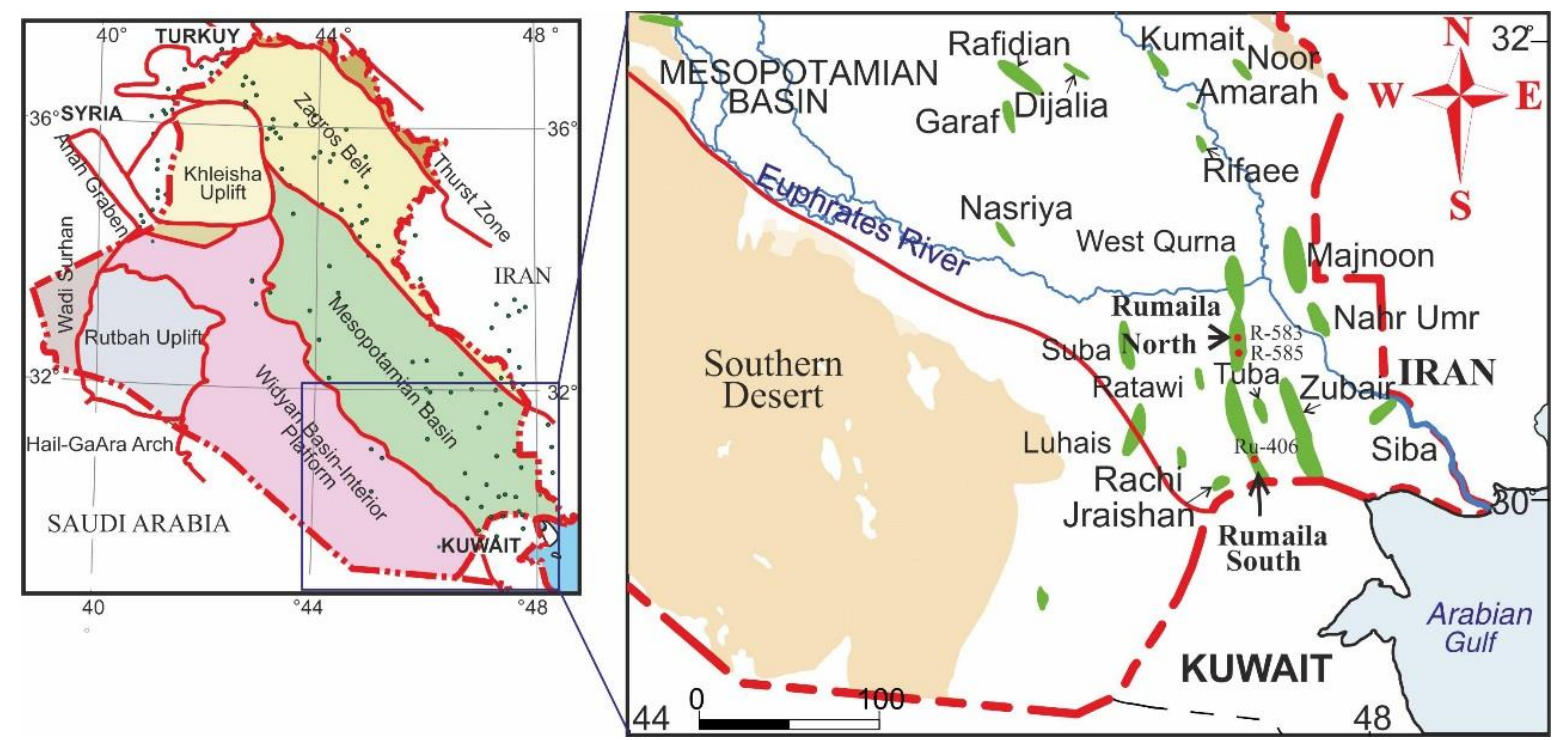

Fig. 1. Left; map of petroleum systems of Iraq (USGS, 2000), and right; location map showing the Zubair Formation among other different oilfields in southern Iraq (Al-Khafaji et al., 2021)

The geometry of terrigenous clastic and oil-bearing sequences in southern Iraqi oilfields has been used to classify them based on their composition (Buday, 1980). The Zubair Formation in southern Iraq was divided into five sections (Owen and Nasser, 1958; Buday, 1980; Al-Jaberi and Al-Jafar, 2020). These are shale members with two distinguished sandstone members and a small amount of siltstone, predominating sandstone with shale and siltstone subsidiary units, black shale, as fissile with occasional sandstone streaks, or greenish black shale, sandstone predominance with subsidiary siltstone beds, and greenish black shale with lenses of sandstone-fissile siltstone. According to Van Bellen et al., (1959), the age of the Zubair Formation is lower Aptian- Hauterivian, based on fossils and geographical similarities, whereas Owen and Nasser (1958) have suggested a lower Aptian- Barremian. The Zubair Formation age in southern Iraq is described as Hauterivian-Barremian whereas the southwestern appearance of Valangenian-Barremian (Al-Zaidy, 2020). Abbo and Safar (1967) and Al-Siddiki (1978) suggested the Hauterivian-Aptian age; while Al-Ameri and Batten (1997) have referred to the Barremian-Early Albian period based on palynofacies (Fig. 2). The Zubair Formation is equivalent to Biyadh Formation in Saudi Arabia in age and lithology (Buday, 1980). The Zubair Formation in Syria (Jabal Abd El-Aziz) is the counterpart of the Lower Sarmord Formation, which is a sandy sequence intertwined with marl and marl limestone (Buday, 1980). To the eastward, the Gadvan Formation in Iran is equivalent to the Zubair Formation, and it partially passes through the neritic facies of the Khasib Formation in Qatar. The location of the studied borehole, depth and thickness of the Zubair Formation are listed in Table 1. The lithological units of the Zubair Formation are illustrated in Fig. 2.

Table 1. Thickness and coordinates and the depth of the Zubair Formation at Rumaila South oilfield $(\mathrm{Ru})$ and Rumaila North oilfield (R) South Mesopotamian Basin, Iraq

\begin{tabular}{ccccc}
\hline Well no. & Top $(\mathbf{m})$ & Bottom $(\mathbf{m})$ & Longitude & Latitude \\
\hline R- 583 & 3078 & 3340 & $47^{\circ} 18^{\prime} 48.96^{\prime \prime} \mathrm{E}$ & $30^{\circ} 31^{\prime} 20.79^{\prime \prime} \mathrm{N}$ \\
R- 585 & 3114 & 3338 & $47^{\circ} 19^{\prime} 57.00^{\prime \prime} \mathrm{E}$ & $30^{\circ} 26^{\prime} 39.02^{\prime \prime} \mathrm{N}$ \\
$\mathrm{Ru}-406$ & 3078 & 3370 & $47^{\circ} 21^{\prime} 21.40 \mathrm{E}$ & $30^{\circ} 21^{\prime} 13.20 \mathrm{~N}$ \\
\hline
\end{tabular}




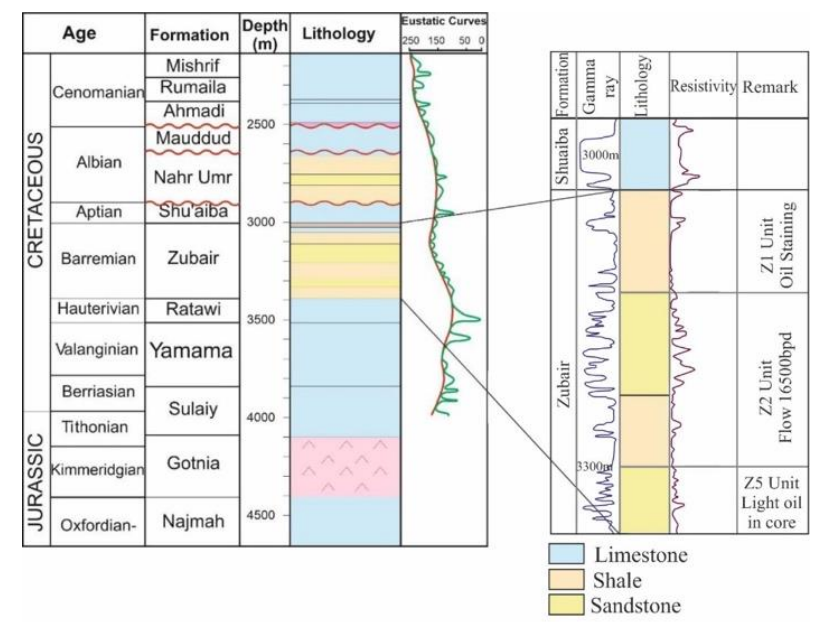

Fig. 2. Stratigraphic section of Well Ru-167, on the left, lithological units of the Zubair Formation (Al-Khafaji et al., 2020)

The aim of the present study is to interpret the depositional environment based on detailed petrographic study, microfacies analysis and geochemistry. Well logs such as gamma ray (GR) and density of relating the log response to facies were conducted as a main requirement of sequence stratigraphic analysis to depict the Zubair Formation sequence development.

\section{Methodology}

The data of cores and wireline logs of the wells Ru- 406 and R 583 and 585 were provided by the Basra Oil Company. A total of 160 core samples were used to prepare thin sections that have been conducted in the laboratories of the Department of Applied Geology of the University of Babylon. The geochemical analysis was carried out in the SPECTRO XEPOS device (Germany made) in the Iraq-Germany laboratory at the Department of Geology, Collage of Science, University of Baghdad. Fifteen core samples were prepared to be ready for XRF analysis. Samples were pulverized to a suitable grain size, pressed into specific small disc. They analyzed for the major oxides $\left(\mathrm{SiO}_{2}, \mathrm{Al}_{2} \mathrm{O}_{3}, \mathrm{Fe}_{2} \mathrm{O}_{3}\right.$, $\mathrm{CaO}, \mathrm{MgO}, \mathrm{Na}_{2} \mathrm{O}, \mathrm{K}_{2} \mathrm{O}$ and $\mathrm{MnO}$ using the XRF method.

The major and minor microfacies, assess diagenetic factors, porosity types, origins, and evolution were studied. Well Logs; Gamma Ray (GR), spontaneous potential (SP) and sonic log were integrated together with microfacies and geochemistry to complement facies identification and correlations in addition to use scanning electronic microscope (SEM). The lithological units, reservoir units, and sedimentary facies were predicted and correlated using available logs (gamma ray and density), as well as stratigraphic correlation. The sequence stratigraphic model used in the present study was based on Emery and Myers (1996); Schlager (2005) and Catuneanu et al. (2009) to approach and terminology.

- Taking cores and cuttings samples from examined wells to prepare thin sections.

- Examine thin sections to identify the petrography and lithofacies study of the studied wells.

- The clastic point counting technique was used to count 500 grains for each thin section.

- Examine the complete collection of well logs to changes in lithofacies distribution.

\section{Results and Discussion}

\subsection{Petrography}

For several purposes, sandstone petrography is particularly important in exploration. Quartz has the most abundant among main component grains forming the Zubair Formation (quartz, feldspar and lithic grains). It formed from $>90 \%$ has a texture showing well sorted, rounded quartz-arenite sandstone unit 
to $<25 \%$ in the same formation's shale-dominated unit. The varies in the Zubair succession of quartz grain size from average to very fine according to the Wentworth scale stated in Pettijohn et al. (1973). Grain roundness varies from subangular to oval depending on the visual map of Powers (1953). Reworking, long transportation distance or tropical weathering predominance may result in the predominance of quartz grains (Dickinson, 1988); and the rounded grains suggest reworked quartz. Such this form of quartz is recorded with an older sandstone derivation, some showing a slight elongation parallel to the bedding. A conchoidal fracture has been observed on some quartz surfaces and attributed to the mechanical transportation impact (Fig. 3a). The roundness of the particle corresponds to the sharpness of the corners and sides of a grain (Boggs, 2006). This role was observed in the most studied samples in different degrees of roundness ranging from angular (Fig. 3b) to round outline shapes. The mechanical transportation of the clasts formed solution pits and groves as dominant characteristics on the grain surfaces (Fig. $3 c$ and d) respectively. Two types of quartz grains are recognized in the Zubair Formation. Monocrystalline quartz makes up most of the quartz forms (Fig. 4a) which is characterized by slight undulatory in most to strong undulatory in few grains. A plutonic source can be this type of quartz, but it may also be derived from other sources (Folk, 1968; Blatt, 1976). A plutonic source can also be represented by undulose quartz where undulosity is produced when the various zones are separated by line-of vacuoles of pebbles indicating traces of healed fracture due to different c-axis orientation (Blatt, 1976; Folk, 1968). Polycrystalline quartz is composed of more than one crystal with various optical orientations (Fig. 4b). They have a higher percentage than undulous quartz, and due to disaggregation of polycrystalline quartz grains and broken undulous quartz, significant amounts of fine size quartz tend to be present. Dynamically, undulous quartz is less stable than nonundulose quartz and appears to break into smaller grains (Blatt et al., 1980). Polycrystalline quartz as a small percentage as a reason for that is the lack of stability during long-distance transport or lack of presence in the source (Pettijohn et al., 1973). The deep burial can cause undulated extinction, but lithostatic pressure alone has only a slight impact on the percentage of grains of undulose quartz (Fuchtbauer, 1974). Metamorphic quartz shows worked undulosity and a high degree of undulosity is found in large plutonic quartz (Pettijohn, 1975).

The percentage of undulose quartz cannot be regarded as a reliable indicator of provenance (Blatt and Christie, 1963; Awadh and Al-Ankaz, 2016). Polycrystalline quartz can be made from the plutonic source, consisting of two or three crystals. Orthoclase and plagioclase were identified in small amount in the Zubair Formation (Figs. $4 \mathrm{c}$ and d). The presence of feldspar or absence corresponds with the balance rate between the decomposition and erosion due to poor stability when it decomposes and erodes during transported long distances (Pettijohn, 1975). The Feldspar ratio is less than 7\% due to the poor stability because of decomposition and erosion when transported to long distances (Pettijohn, 1975). Deferent rock fragments are existed, some of them represented by chert (Fig. 4e).

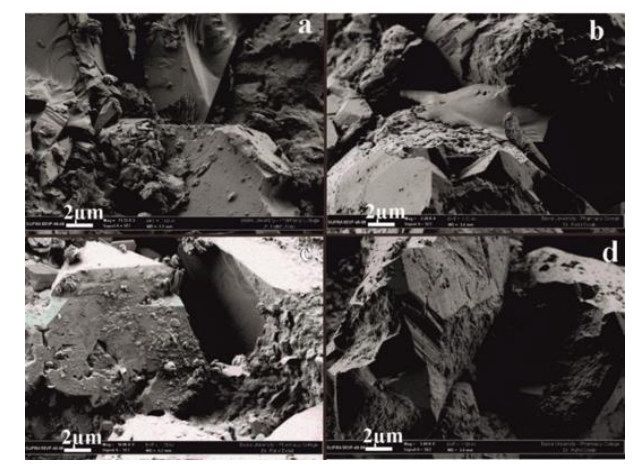

Fig. 3. Backscattered image by using SEM techniques shows: a: the conchoidal fracture of quartz grain

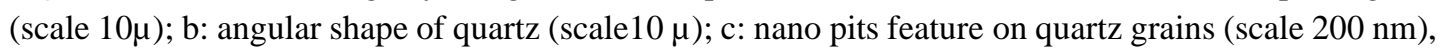
grooves on quartz grain surface in core sample of magnification of $2 \mu$ 


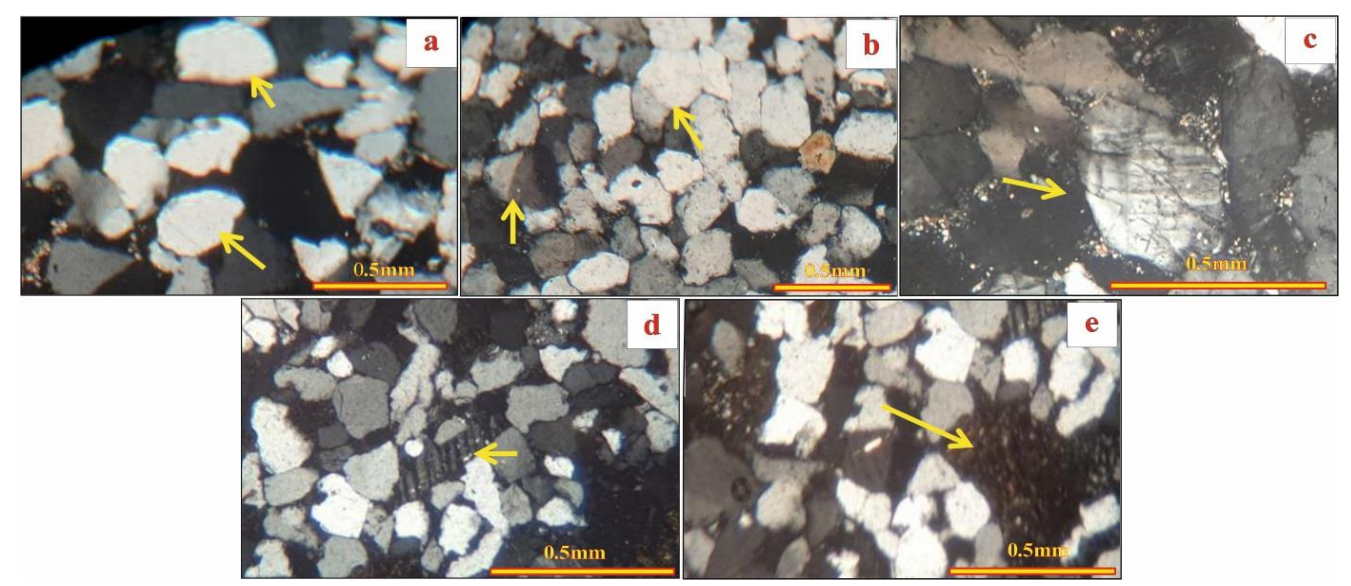

Fig. 4. a. Monocrystalline quartz; b. Polycrystalline quartz; c. Orthoclase feldspar; d. Plagioclase feldspar and e. Chert fragment

\subsection{Provenance of the Zubair Sandstone}

The lithological form of the provenance region controls the mineral composition of the sandstones and tectonic effects influence this in turn (Folk, 1968). The provenance rock type describes the composition of the sediment rather than the atmosphere and relief effects in areas of high tectonic activity (Dickinson, 1988). He has noted that by analyzing the detrital modes of siliciclastic strata in various depositional basins, provenance rocks could provide accurate analysis of the plate tectonic settings and creation of the clastic source region (Dickinson, 1985). Regarding this concept, Dickinson (1988) has introduced a detrital sandstone composition model for major sandstone area types such as stable cartons, basement uplifts, magmatic arcs, and recycled origins. The Zubair Formation characterized by high quartz content; referring to a high textural and mineralogical maturity resulted from long transportation, weathering, sorting, and abrasion. The findings indicate that clasts could have passed through many sedimentation cycles in a quite tectonics of the source area and deposition environment. The petrographic model of the Zubair sandstone have been calculated. Depending on the provenance diagram established by Dickinson (1988), the Zubair clasts are of craton interior (Fig. 5).

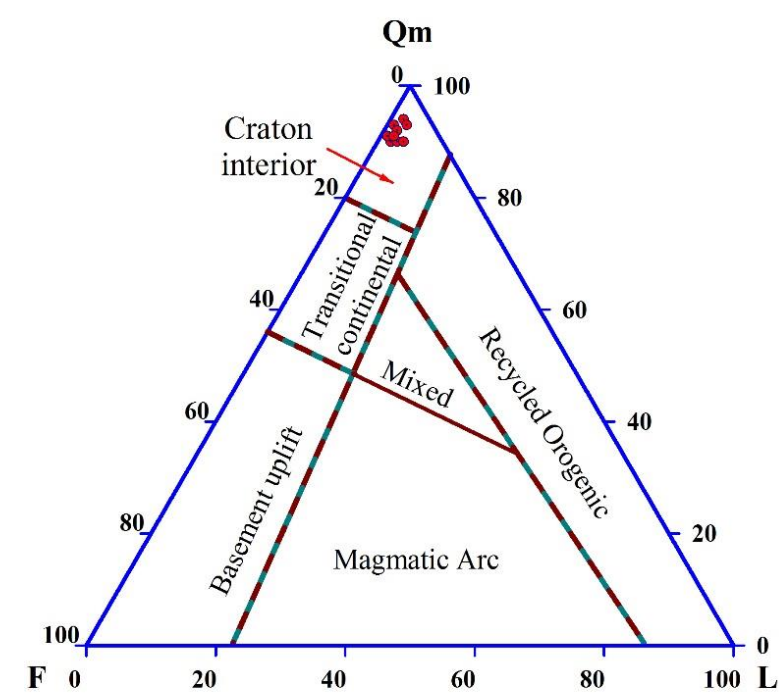

Fig. 5. Provenance of the Zubair Formation; Qm is a monocrystalline quartz grain; F is a feldspar grain and L represents lithic grains including polycrystalline quartz; Diagram after Dickinson (1988) 


\subsection{Facies Analysis}

The sedimentology and reservoir properties of clastic sedimentary rocks are depended on the interplaying of tectonic development, sea level changes, rate of sediments supplying, physical and biologic activity, Processes of sediments transportation and sedimentation, and climatic changes. These processes interact at the basin scale to create the geometric arrangement and distribution over time of various sedimentary environments or stratigraphic tracts, known as the stratigraphic architecture of the basin (Miall, 1991, Al-Dabbas et al., 2014). In the Zubair Formation, five lithofacies were defined as follows.

\subsubsection{Well sorted quartz arenite sandstone lithofacies $(f-1)$}

Lithofacies are characterized by fine-grained well sorting sandstone with sub-angular to sub-rounded grain form mode (Fig. 6a). In these lithofacies, the sandstone beds consist of more than 90 percent of quartz to be known as quartz arenite sandstone. This is seen in the middle unit as very low gamma-ray values and high resistivity values with gamma-ray log box form mode in addition to spontaneous potential logs (Figs. 10, 11, and 12).

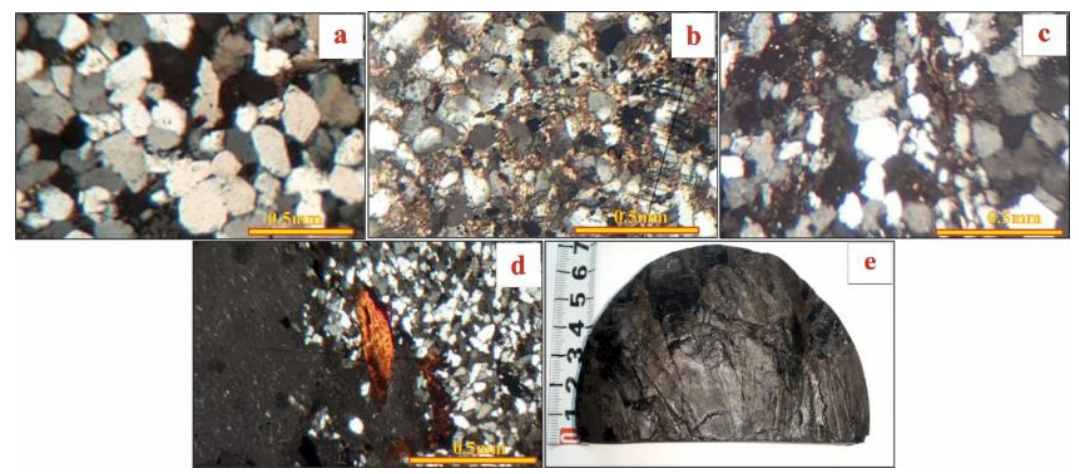

Fig. 6. Zubair lithofacies a. Well-sorted quartz arenite sandstone; b. Poorly sorted quartz arenite sandstone; c. Clayey sandstone poorly sorted; d. Sandy shale; and e. Shale

\subsubsection{Poorly sorted quartz arenite sandstone lithofacies (F-2)}

This facies represents a broad range of sand grain sizes within the sandstone unit, from medium to coarse sand size, and well-rounded to sub-rounded grain form mode. In these lithofacies, the sandstone contains approximately more than $90 \%$ of quartz to be identified as quartz arenite that appeared in the upper Zubair Formation (Fig. 6b). These lithofacies appear poorly sorted with very low gamma-ray values that decrease upward with gamma-ray log bell form mode and high resistivity log values (Figs. $10,11,12)$.

\subsubsection{Clayey sandstone poorly sorted lithofacies (F-3)}

These lithofacies are described as muddy sandstone consisting primarily of rocks dominated by quartz. It is characterized by poorly sorted greywacke sandstone mode (Fig. 6c); with moderate gamma-ray values as the mode of funnel form (Figs. 10, 11, and 12). These lithofacies are seen as muddy rocks in the upper and lower units of the Zubair succession.

\subsubsection{Sandy shale lithofacies (F-4)}

They are existed as shale lenses in the sandstone members, distinguished by elevated V-shale values with funnel shape mode (Figs. 10, 11, and 12). Mud dominated rocks with quartz grains of angular grain form are the main components of these facies (Fig. 6d). 


\subsubsection{Shale lithofacies $(F-5)$}

The shale lithofacies is existed in all parts of the Zubair succession composing of shale dominated rocks with high organic matter (Fig. 6e), with high values of gamma-ray as bell mode shaped (Figs. 10, 11, and 12).

\subsection{Geochemical Analysis}

The geochemical results of the Zubair clasts are presented in Table 2. These analyses aid to reconstruct the deposition processes of sandstone samples, accordingly, the major oxides ratios $\left[\mathrm{Al}_{2} \mathrm{O}_{3}\right.$ (A) $\left.-\left(\mathrm{K}_{2} \mathrm{O}+\mathrm{Na}_{2} \mathrm{O}+\mathrm{CaO}\right)(\mathrm{K})-\left(\mathrm{Fe}_{2} \mathrm{O}_{3}+\mathrm{MgO}\right)(\mathrm{F})\right]$ are plotted on AKF ternary classification diagram established by Englund and Jorgensen (1973) showing continental and transition depositional environment (Fig. 7). Geochemistry of clasts provided good information of lithofacies assemblage proxies that can be used to infer paleoenvironment conditions. The value of $\mathrm{Fe} / \mathrm{Mn}$ indicates a shallow environment (Fig. 8).

Table 2. Major oxides of the Zubair Formation clasts obtained from analyzing core samples

\begin{tabular}{cccccccccc}
\hline \multirow{2}{*}{ Core } & $\mathbf{S i O}_{2}$ & $\mathbf{A l}_{2} \mathbf{O}_{3}$ & $\mathbf{F e}_{2} \mathbf{O}_{3}$ & $\mathbf{C a O}$ & $\mathbf{M g O}$ & $\mathbf{N a}_{2} \mathbf{O}$ & $\mathbf{K}_{2} \mathbf{O}$ & $\mathbf{M n O}$ & \multirow{2}{*}{} \\
\cline { 2 - 9 } & \multicolumn{7}{c}{$\mathbf{F e} / \mathbf{M n}$} \\
\hline 1 & 97.29 & 0.66 & 1.82 & 0.14 & 0.02 & 0.04 & 0.01 & 0.009 & 91.37 \\
2 & 93.34 & 2.55 & 2.15 & 1.16 & 0.66 & 0.03 & 0.21 & 0.015 & 64.76 \\
3 & 95.25 & 0.51 & 1.79 & 1.84 & 0.56 & 0.04 & 0.01 & 0.016 & 50.55 \\
4 & 98.07 & 0.75 & 1.87 & 0.19 & 0.07 & 0.04 & 0.02 & 0.01 & 84.49 \\
5 & 97.66 & 0.97 & 1.07 & 0.13 & 0.03 & 0.1 & 0.03 & 0.006 & 80.57 \\
6 & 94.19 & 1.71 & 1.81 & 1.61 & 0.32 & 0.01 & 0.36 & 0.016 & 51.11 \\
7 & 93.44 & 2.16 & 2.52 & 1.15 & 0.03 & 0.12 & 0.57 & 0.007 & 162.65 \\
8 & 94.55 & 3.21 & 1.92 & 0.05 & 0.13 & 0.06 & 0.07 & 0.009 & 96.39 \\
9 & 98.07 & 0.56 & 1.92 & 0.39 & 0.03 & 0.01 & 0.02 & 0.007 & 123.93 \\
10 & 97.07 & 0.53 & 1.83 & 0.93 & 0.22 & 0.01 & 0.01 & 0.015 & 55.12 \\
11 & 91.44 & 7.15 & 1.32 & 0.04 & 0.07 & 0.04 & 0.12 & 0.007 & 85.20 \\
12 & 92.51 & 6.14 & 1.14 & 0.02 & 0.04 & 0.06 & 0.09 & 0.006 & 85.85 \\
13 & 98.24 & 0.77 & 1.8 & 0.03 & 0.01 & 0.01 & 0.14 & 0.006 & 135.55 \\
14 & 96.71 & 1.25 & 1.08 & 0.7 & 0.06 & 0.02 & 0.18 & 0.007 & 69.71 \\
15 & 98.43 & 0.36 & 1.85 & 0.28 & 0.06 & 0.01 & 0.01 & 0.006 & 139.31 \\
\hline
\end{tabular}

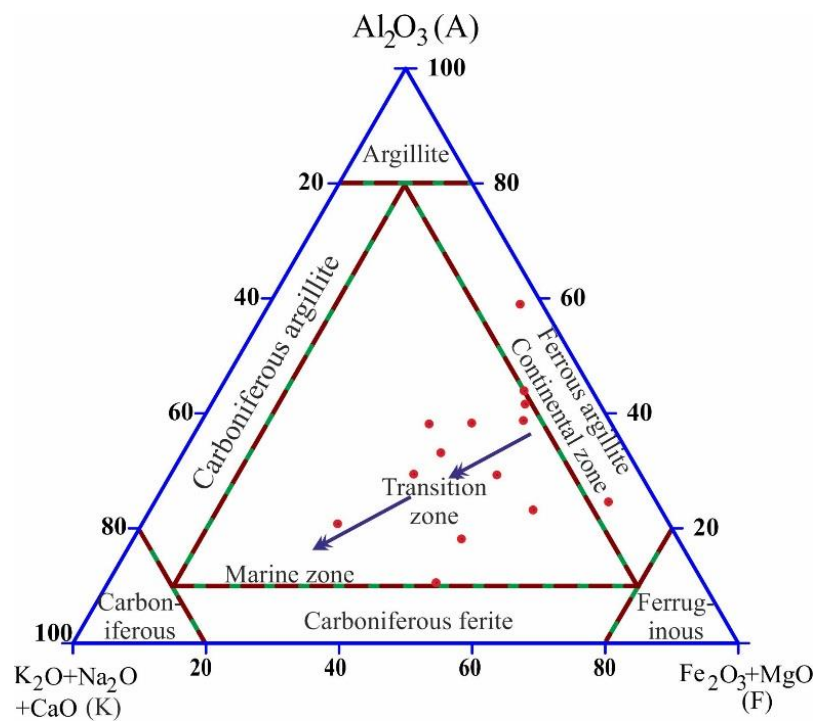

Fig. 7. Gradual transition of the Zubair clasts from freshwater basin to marine environment diagram after Englund and Jorgensen (1973) 


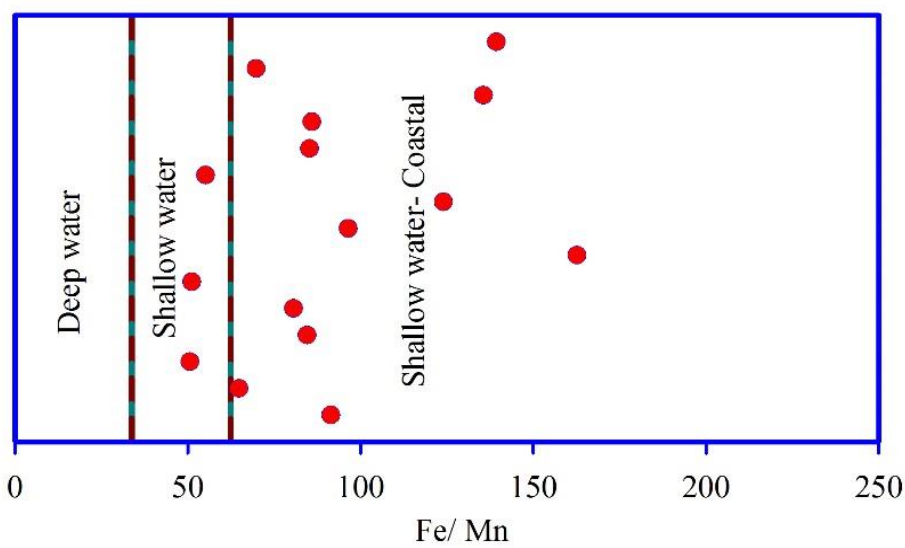

Fig. 8. Deposition environment of the Zubair Formation sediment, diagram after Ratcliffe et al. (2007)

The higher concentration of $\mathrm{MgO}$ indicates marine lithofacies; the lower indicates terrestrial lithofacies. For the easy distinction between marine and deltaic to nonmarine sandstones, (Ratcliffe et al., 2007) established a ternary diagram based on major oxide. The ternary diagram $\left(\mathrm{MgO}-\mathrm{SiO} 2 / \mathrm{Al}_{2} \mathrm{O}_{3}\right.$ - $\mathrm{Fe}_{2} \mathrm{O}_{3}$ ) confirms a formation condition associated with deltaic to nonmarine assemblages (Fig. 9).

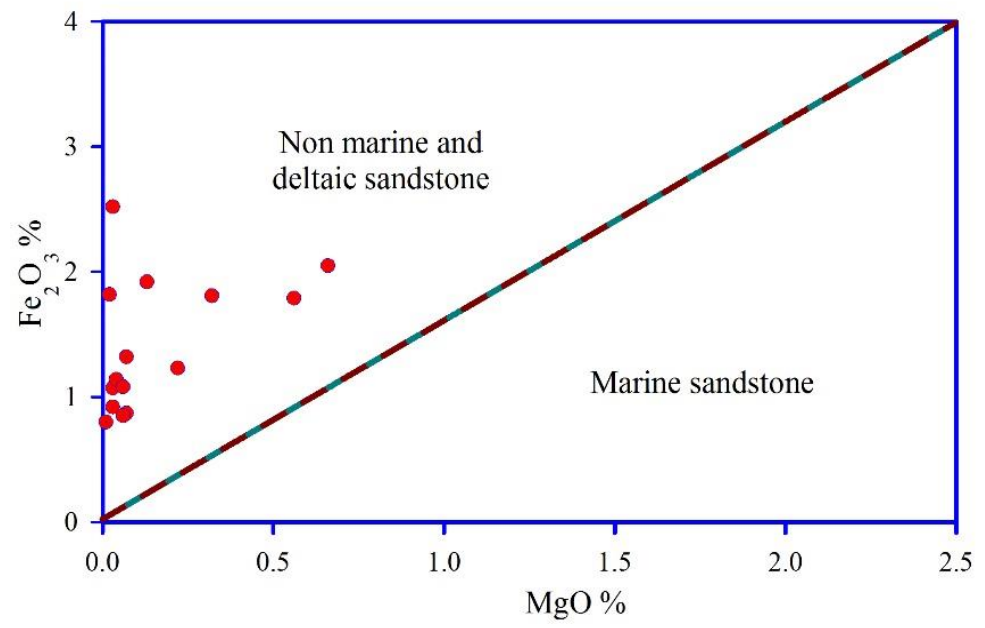

Fig. 9. Characterization and differentiation of marine from nonmarine units of the Zubair clasts; diagram after Ratcliffe et al. (2007)

\subsection{Depositional Environment}

The delta plain, backshore, and delta front depositional conditions are the main facies distinguished according to Emery and Myers (1996). The minor lithofacies change and the general pattern of grain size sediments were assessed based on the well logging methods (GR, SP, and sonic logs) beside geochemistry showed. They clarified the Zubair clasts are of transitional environments changed from basins from freshwater to marine environment (Fig. 7). The sandstone composite which is the main component of the lower unit is divided into the upper part which is composed of shale and the lower part which is composed of sandstone layers in the northern part of the studied area (R- 583 and R-585) while the south shows one part dominated by shale Ru- 406. Clayey sandstone poorly sorted Lithofacies (F-3) is the major lithofacies in this unit and well sorted quartz arenite sandstone lithofacies (F-.1) at the top. Awadh et al, (2014) recorded a lot of kaolinite in the Zubair Formation, which is involved nearshore 
line, or fresh water in tropical climate (Velde, 1977). The lower part is characterized by the presence of shale lithofacies (F-5). This sequence is interpreted as sedimentation in the delta front environments and backshore in the R-583 and the delta plain and backshore environments in the R-585 as common in the northern part of the studied area (Figs. 10 and 11), while the southern part $\mathrm{Ru}-406$ represented by delta plain and back shore environments. The relationship between $\mathrm{MgO}$ and $\mathrm{Fe}_{2} \mathrm{O}_{3}$ confirms a formation condition associated with deltaic to nonmarine assemblages (Fig. 9).

Alternating shale and sandstone beds are characterized as the middle unit of the Zubair Formation. In the north of the studied area (R-583), the middle part is represented by poorly sorted quartz arenite sandstone lithofacies (F-2) as a delta plain unique association facies and shore face association facies. The clayey sandstone poorly sorted lithofacies (F-3) is an alternative with shale lithofacies (F-5) to the south direction (R-585), whereas the south shows well-sorted quartz arenite sandstone lithofacies (F-1). The delta plain is a common existed in R-585 and the delta plain is an alternative with backshore to the north direction (R-583 and R-585) (Figs. 10, 11 and 12).

The main lithofacies in this unit is well-sorted quartz arenite sandstone lithofacies (F-1). The increase in Fe/Mn value indicates shallow-depth sedimentation (Fig.7). The size of the maritime lithofacies increases as the amount of $\mathrm{MgO}$ increases, whereas the size of the terrestrial lithofacies diminishes (Ratcliffe et al., 2007). This represents the delta front associated facies, while in the lower zones of this part the clayey sandstone poorly sorted lithofacies (F-3) and sandy shale lithofacies (F-4). It represented the delta plain associated facies (Figs. 10, 11 and 12).

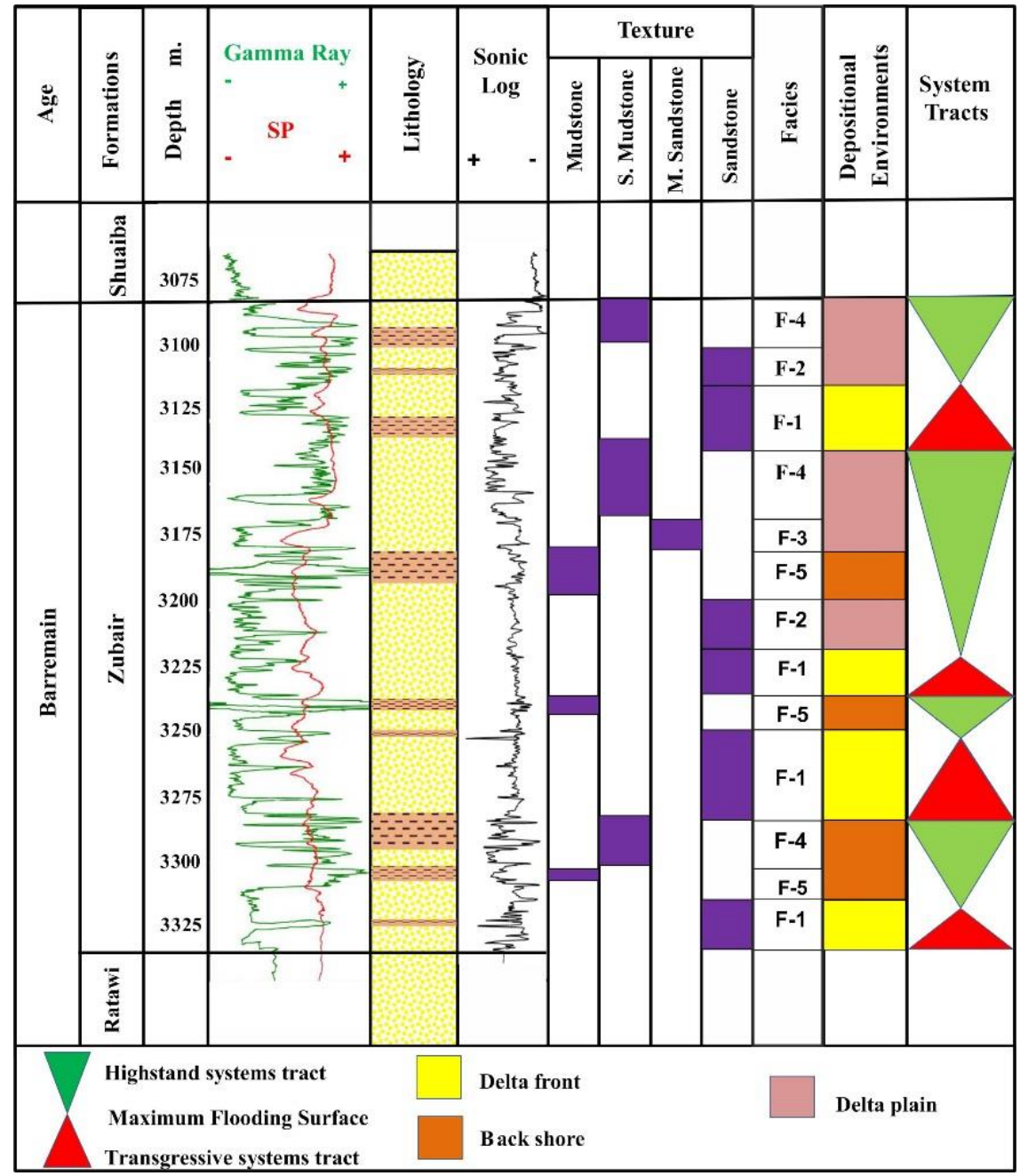

Fig. 10. Sequence stratigraphy subdivision of Zubair Formation at R-583 


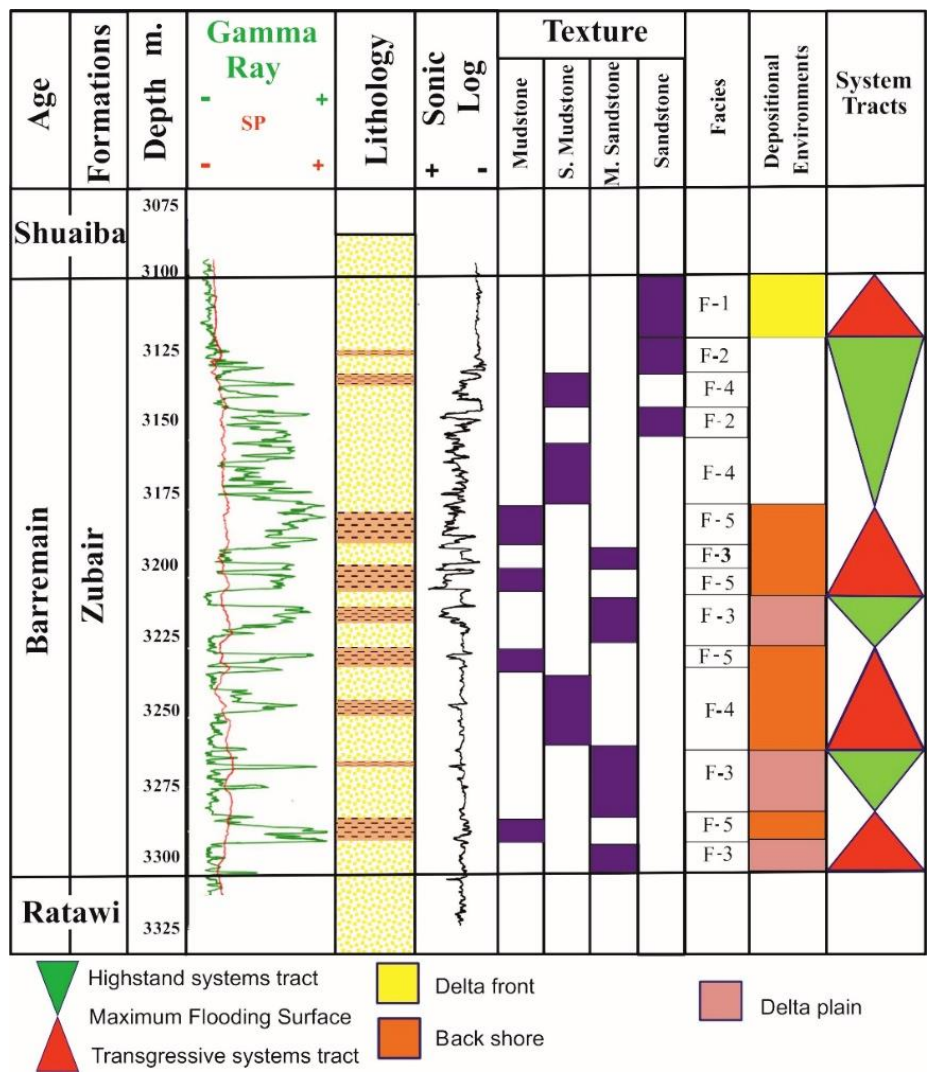

Fig. 11. Sequence stratigraphy subdivision of Zubair Formation at R- 585

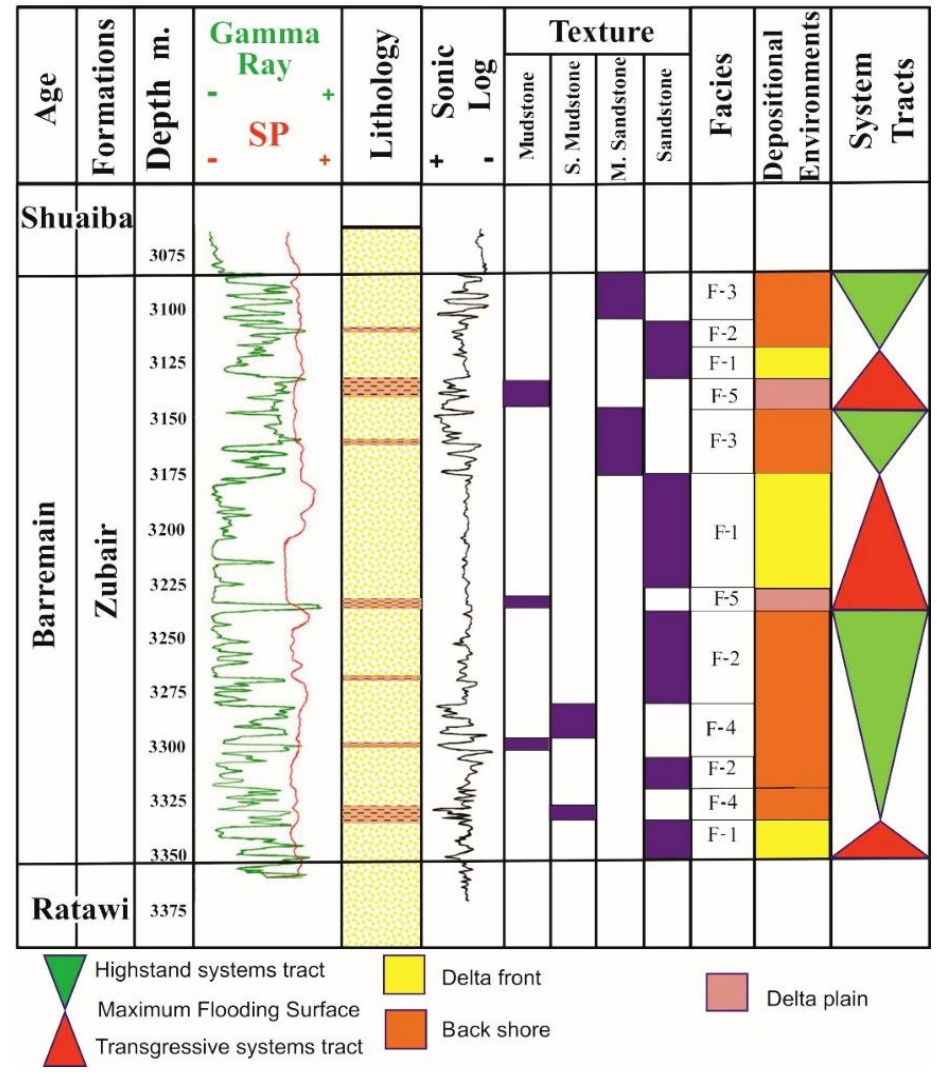

Fig. 12. Sequence stratigraphy subdivision of Zubair Formation at Ru- 406 


\subsection{Sequence Development of the Zubair Formation}

The Zubair Formation is made up of the eroded Arabian Shield and the stable Shelf Arabian Platform, which were uplifted during the Jurassic (Late Kimmerian) movement. These clasts were transported to the sea through deltas across the Lower Cretaceous geosyncline's foreland. Under alluvial conditions, the Arabian Shield is thought to have supplied the Biyadh Formation in Saudi Arabia (Ali and Nasser, 1989). The mouth bar facies dominate the upper sandstone portion of the Zubair Formation, resulting in the top of the succession that can be used to track the progression of the depositional series. The top sediments are mostly of marsh deposits, although there are some river channel deposits and natural levee deposits (Reineck and Singh, 1980). The Zubair Formation sediments were deposited during the early stages of the Alpine geosyncline basin growth and the continent progressive rise. As a result, the paleogeographic environment was marked by an association between geosyncline motions and those triggered by these movements on the Arabian Shield (Buday, 1980). The upper sandstone in the Zubair Formation is mirrored in another topmost delta sediment where the channel facies moves to the sea and the forest sediments are made up of pro-delta silty clay and very coarse sandstone, siltstone, and claystone. The siliciclastic shelf evolved from delta depositional mode to lacustrine mode during the Zubair Formation deposition. A sequence boundary type-1 separates the basinal shale of Ratawi Formation from the overlying delta influenced lower Zubair Formation (Figs. 10, 11, and 12).

Backshore related facies occupy the lower part of the Zubair Formation. They discovered that multistoried mode and multilateral adjustments deltaic channel sandstone bodies were vertically separated, resulting in compartmentalized reservoir design. The transgressive system tract (TST) is defined by the appearance of the back shore aligned with facies that overlay the unconformity surface (SB1). This stage ended when channel fill deposits emerged in the delta plain, indicating a high stand structure tract (HST), with the fluctuation point between the TST and HST representing a maximal flooding surface. The transgressive system tract of the Zubair Formation is prominent in the lower part of the formation and the depositional sequence which comprises retrgradational parasequences units, separated from each other by deep water marine transgressive sediments which mark a maximum flooding surface that separating the transgressive from high stand system tract. The middle part of the Zubair Formation is distinguished by quartz arenite sandstone that is moderate to well sorted, with shale bands overlying the sand body. During the transgressive period, this succession was deposition in the delta front ecosystem with measures of sea level increase. In this part, three TST sequences end with the highest sea level rise (MFS) to mark the upper part of the Zubair Formation.

During the HST, high amounts of organic matter and pyrite indicating that the sedimentary environment has been reduced to a marshy environment (Figs. 10, 11 and 12). The Zubair Formation highstand system tract may be identified by fluvial facies prograding over tidal facies or tidal flat facies prograding over shallow coastal facies, all of which are bounded below by maximal flooding surface. The Zubair Formation upper portion revealed a shallower area of shale-dominated rocks containing high organic matter and pyrite. When the deposition environment shifted from delta front and delta plain to highstand level, this signaled fining up-ward mod. The end of this stage was indicated by the deposition of the upper part of the Zubair Formation, and the starting of the Shuaiba Formation as a shallow carbonate marine (Figs. 10, 11 and 12).

\section{Conclusions}

This study draws many findings as follows:

- The Zubair Formation in Rumaila (South and North) oilfields, southern Iraq has deposited in delta plain, back shore, and delta front depositional conditions representing five lithofacies well-sorted quartz arenite sandstone, poorly sorted quartz arenite sandstone, clayey sandstone poorly sorted, sandy shale, and shale. 
- The Zubair clasts were deposited in transitional environments that gradual transition of sediments of the basin from freshwater to marine environment forming several fourth-order cycles representing fluctuations of sea level rises and stillstands of the relative sea level controlling by tectonics.

- The Zubair Formation in the studied wells contains several asymmetric cycles of the fourth degree, as the asymmetry of these cycles is due to the relative variance of sea level and sediment supply, which reflects the time of sea level rise after a period of stillness.

- A sequence boundary type-1 separates the basinal shale of the Ratawi Formation from the overlying delta influenced lower Zubair Formation. The Zubair Formation upper sandstone part are repeated again for delta, where channel facies shift to the sea and forest deposits comprise of pro-delta silty clay and very coarse sandstone, siltstone, and claystone. The siliciclastic shelf transitioned from delta to lacustrine depositional mode. The Zubair Formation lower part is occupied by backshore-related facies.

- The deltaic channel sandstone bodies were vertically divided due to multistoried mode and multilateral changes, resulting in compartmentalized reservoir configuration. The presence of the back shore aligned with facies that overlay the unconformity surface defines TST and (SB1). As channel fill deposits appeared in the delta plain, suggesting a HST and this stage ended, with the fluctuation point between the TST and the HST marking the maximum flooding surface.

- The moderate to well sorted quartz arenite sandstone with shale strata overlying the sand body are characterized the middle part of the Zubair Formation. This succession was deposited in the delta front environment with sea-level rise during the transgressive.

- The upper part of the Zubair Formation is marked by three TST sequences that end with the maximum sea-level rise (MFS). The sedimentary ecosystem has been changed to a marsh conditions due to the High levels of organic matter and pyrite existing during the HST. The upper Zubair Formation is of shallow environment dominated by black shale and pyrite.

- The finning upward mode was indicated when the deposition environment changed from delta front and delta plain to a highstand stage. The deposition of the upper part of the Zubair Formation and the beginning of the Shuaiba Formation mark the end of this stage as shallow carbonate marine.

\section{Acknowledgements}

The authors are very grateful to the Iraqi Oil Exploration Company and Basra Oil Company for obtaining the required data and samples. The authors are also very grateful to the head and technicians of the Department of Applied Geology at the College of Science, University of Babylon and Geochemical lab at the Department of Geology, the University of Baghdad for the facilities provided. The authors are greatly indebted to the two anonymous reviewers for their constructive and valuable suggestions to improve the manuscript, and very grateful to the Secretary of Journal Mr. Samir R. Hijab and the Technical Editors for their great efforts and valuable comments.

\section{References}

Abbo, A.S., and Safar, V. M., 1967. Sand and Shale Correlation in the Zubair and Rumaila Oilfields. Sixth Arab Petroleum Congress, Baghdad, Iraq, March 6-13, 16.

Al-Ameri, T. K., and Batten, D. J. 1997. Palynomorph and palynofacies indications of age, depositional environments and source potential for hydrocarbons: lower cretaceous Zubair Formation, southern Iraq. Cretaceous Research, 18(6), 789-797.

Al-Dabbas, M.A., Awadh, S.M. and Zaid, A.A., 2014. Facies analysis and geochemistry of the Euphrates Formation in Central Iraq. Arabian Journal of Geosciences, 7(5), 1799-1810. 
Ali, A.J., and Nasser, M.E., 1989. Facies analysis of the L. Cretaceous oil-bearing Zubair Formation in southern Iraq. Modern Geology, 13; 225-242.

Al-Jaberi M. H., and Al-Jafar M. Kh., 2020. Elements distribution for the upper sandstone member of the Zubair Formation in Zubair oil field, southern Iraq. Iraqi Geological Journal, 53(1E), 55-74

Al-Khafaji, A.J., Hakimi, M.H., El-Khedr, I., Najaf, A.A., Al Faifi, H., and Lashin, A., 2020. Organic geochemistry of oil seeps from the Abu-Jir Fault Zone in the Al-Anbar Governorate, western Iraq: Implications for early-mature sulfur-rich source rock. Journal of Petroleum Science and Engineering, 184, 106584.

Al-Khafaji, A.J., Hakimi, M.H., Mohialdeen, I., Idan, R.M., Afify, W.E., and Lashin, A.A., 2021. Geochemical characteristics of crude oils and basin modelling of the probable source rocks in the Southern Mesopotamian Basin, South Iraq. Journal of Petroleum Science and Engineering, 196, 107641.

Al-Naqib, K.M., 1985. Geology of the Arabian Peninsula South Western Iraq (2 ${ }^{\text {nd }}$ edition). U.S. Geological Survey, $61 \mathrm{pp}$.

Al-Siddiki, A.A.M., 1978. Subsurface Geology of Southern Iraq. Tenth Arab Petroleum Conference, Tripoli, Libya, August 47 pp.

Al-Zaidy, A. A., 2020. Facies architecture and stratigraphic sequence of Zubair Formation in Majnoon and Suba oil fields, Southern Iraq. Modeling Earth Systems and Environment, 6, 779-792.

Awadh S. M., 2018. Physico-chemical characterization and salinity distribution of the oilfield water in the upper member of Zubair sandstones in Rumaila north oilfield, southern Iraq. Iranian Journal of Oil \& Gas Science and Technology, 7(1), 20-39.

Awadh, S. M., Al-Yaseri, A.A. and Hussein, A. R., 2014. The influence of Kaolinite and pH on permeability in the Zubair reservoir in the North Rumaila Oilfield, Southern Iraq. Iraqi Journal of Science, 55(2B),780-789.

Awadh, S.M. and Al-Ankaz, Z.S., 2016. Geochemistry and petrology of Late Miocene-Pleistocene Dibdibba sandstone formation in south and central Iraq: implications for provenance and depositional setting. Arabian Journal of Geosciences, 9(8), 1-14.

Awadh, S.M., Al-Auweidy, M.R. and Al-Yaseri, A.A., 2019. Hydrochemistry as a tool for interpreting brine origin and chemical equilibrium in oilfields: Zubair reservoir southern Iraq case study. Applied Water Science, 9(3), 1-12.

Bellen, R.C. Van, Dunnington, H.V., Wetzel, R. and Morton, D., 1959. Lexique Stratigraphique International, Asia (Iraq). International Commission on Stratigraphy, Paris, 333 pp.

Blatt, H. and Christie, J.M., 1963. Undulatory extinction in quartz of igneous and metamorphic rocks and its significance in provenance studies of sedimentary rocks. Journal of Sedimentary Research, 37(4), 1031-1044.

Blatt, H., 1967. Provenance determinations and recycling of sediments. Journal of Sedimentary Petrology, 6, 779-792.

Blatt, H., Middleton, G. and Murray, R., 1980. Origin of Sedimentary Rocks ( $2^{\text {nd }}$ edition). Prentice-Hall, New Jersey, USA, $782 \mathrm{pp}$.

Boggs, S.J., 2006. Principle of Sedimentology and Stratigraphy ( $4^{\text {th }}$ edition). Prentice- Hall, New York, U.S.A., $662 \mathrm{pp}$.

Buday, T., 1980. The Regional Geology of Iraq, VI: Stratigraphy and Paleogeography, State Organization for Minerals. Dar Al-Kutab publication House, Mosul, Iraq, 445 pp.

Catuneanu, O., Abreu, V., Bhattacharya, J.P., Blum, M.D., Dalrymple, R.W., Eriksson, P.G., Fielding, C.R., Fisher, W.L., Galloway, W.E., Gibling, M.R., Giles, K.A., Holbrook, J.M., Jordan, R., Kendall, C.G.St.C., Macurda, B., Martinsen, O.J., Miall, A.D., Neal, J.E., Nummedal, D., Pomar, L., Posamentier, H.W., Pratt, B.R., Sarg, J.F., Shanley, K.W., Steel, R.J., Strasser, A., Tucker, M.E. and Winker, C., 2009. Towards the standardization of sequence stratigraphy. Earth-Science Reviews, 92(1-2), 1-33.

Dickinson, W.R., 1985. Interpreting provenance relation from detrital modes of sandstones. In: Zuffa, G.G., Provenance of Arenites. Springer, Dordrecht, Holland, 333-361.

Dickinson, W.R., 1988. Provenance and sediment dispersal in relation to plate tectonic and paleogeography of sedimentary basins. In: Klienspehn, K.L. and Paola, C. (eds.), New Perspectives in Basin Analysis, Springer-Verlag, New York, 3-25. 
Dickinson, W.R., and Suczek, C.A., 1979. Plate tectonics and sandstone compositions. American Association of petroleum Geologist, 63: 2164-2182.

Emery, D., and Myers, K.J., 1996. Sequence Stratigraphy. Blackwell Science, Oxford, 297 pp.

Englund, J.O., and Jorgensen, D.P., 1973. A chemical classification system for argillaceous sediments and factors affecting their composition. Geologiska Föreningens in Stockholm Förhandlingar, 95(1), 87-97.

Folk, R.L., 1968. Petrology of Sedimentary Rocks. Hemphill, Austin, Texas, USA, 170 pp.

Fuchtbauer, H., 1974. Sediments and Sedimentary Rocks. Schweizerbartsche Verlagsbu-chhandlung, Stuttgart, 464 pp.

Jassim, S.Z., and Goff J.C., 2006. Geology of Iraq. Dolin, Prague and Moravian Museum, Zelny, Brno, Czech Republic, $341 \mathrm{pp}$.

Miall, A.D., 1991. Principles of Sedimentary Basin Analysis ( $2^{\text {nd }}$ edition). Springer-Verlag, New York, U.S.A., $668 \mathrm{pp}$.

Oldham, V.E., Siebecker, M.G., Jones, M.R., Mucci, A., Tebo, B.M., and Luther, G.W., 2019. The speciation and mobility of Mn and Fe in estuarine sediments. Aquatic Geochemistry, 25, 3-26.

Owen, R.M.S., and Nasser, S.N., 1959. The stratigraphic of Kuwait-Basrah area. In: weeks L.G. (eds.), habitat of oil, American Association of petroleum Geologist special publication, 1252-1278.

Pettijohn, F.J., 1975. Sedimentary Rocks, (3rd edition). Harper and Row, New York, 628 pp.

Pettijohn, F.J., Potter, P.E., and Siever, R., 1973. Sand and Sandstone. Springer-Verlag, New York, 618 pp.

Powers, M.C., 1953, A new roundness scale for sedimentary particles. Journal of Sedimentary Petrology, 23, 117-119.

Ratcliffe, K.T., Morton, A.C., Ritcey, D.H., and Evenchick, C.A., 2007. Whole-rock geochemistry and heavy mineral analysis as petroleum exploration tools in the Bowser and Sustut basins, British Columbia, Canada. Bulletin of Canadian petroleum geology, 55, 4,320-336.

Reineck, H.E., and Singh, I.B., 1980. Depositional Sedimentary Environment (2 ${ }^{\text {nd }}$ edition). Springer-Verlag, Berlin, 549 pp.

Roudgarmi, P., and Farahani, E., 2016. Characterization of sand dunes to detect the sand source and their stabilization, Abardaj, Iran. International Journal of Geography and Geology, 5(1), 1-9.

Schlager, W., 2005. Carbonate Sedimentology and Sequence Stratigraphy. SEPM Society for Sedimentary Geology, Oklahoma, U.S.A., 209 pp.

Scholle, P.A., 1981. A Color Illustrated Guide to Constituents, Textures, Cements, and Porosities of Sandstones and Associated Rocks. American Association of Petroleum Geologists, Tulsa, Oklahoma, U.S.A., 202 pp.

Suttner, L.J., and Dutta, P.K., 1986. Alluvial sandstone composition and paleoclimate. L. Framework mineralogy. Journal of Sedimentary Petrology, 56, 329-345.

Velde, B., 1977. Clays and clay minerals in natural and synthetic systems. Elsevier Scientific Publishing Company, Amsterdam, Netherlands, 227 pp. 